\title{
Anemia megaloblástica y gastritis atrófica
}

Se define como anemia a la disminución de glóbulos rojos (hematíes) o hemoglobina ( $\mathrm{Hb}$ ) por debajo de los valores normales para el sexo y la edad $(\mathrm{Hb}<12 \mathrm{~g} / \mathrm{dl}$ en mujeres; $\mathrm{Hb}<$ $13 \mathrm{~g} / \mathrm{dl}$ en varones), lo que implica una disminución en la capacidad de transporte del oxígeno a los tejidos, produciendo los síntomas típicos de cansancio, mareo y taquicardia. La anemia se puede clasificar en función del tamaño de los hematíes establecido por el volumen corpuscular medio (VCM). Las anemias macrocíticas son aquellas en las que los hematíes tienen un tamaño mayor del normal (VCM > $100 \mathrm{fl}$ ). Las anemias megaloblásticas son anemias macrocíticas en las que los progenitores de los hematíes de la médula ósea presentan alteración en la síntesis de ADN. La causa más frecuente de anemia megaloblástica es la carencia de vitamina B12 o de ácido fólico. Estos nutrientes son imprescindibles para el correcto desarrollo de la hematopoyesis (producción de glóbulos rojos por la médula ósea) y están implicados en la formación de la mielina de las neuronas y del tubo neural durante el periodo embrionario. Su déficit produce anemia, alteraciones del sistema nervioso y aumento de una proteína, la homocisteína, con el consiguiente aumento de riesgo trombótico.

La vitamina B12 o cobalamina se sintetiza por bacterias intestinales, pero se pierde en su mayor parte por las heces, por lo que es necesario un aporte diario en la dieta de unos $2,5 \mathrm{mcg}$. Una dieta equilibrada posee de 7 a $30 \mathrm{mcg}$, aportado por todo tipo de alimentos. Únicamente las dietas vegetarianas estrictas carecen de cobalamina. La vitamina B12, una vez ingerida, se separa de las proteínas gracias al pH ácido de estómago y a las enzimas pancreáticas. La cobalamina libre se une al factor intrínseco producido por las células parietales del estómago, lo que permite que sea absorbida (pasa a la sangre) en el último tramo del intestino delgado (íleon). Los depósitos de cobalamina se localizan en el hígado, siendo muy abundantes $(2-5 \mathrm{mg})$, lo que hace que su déficit tarde años en manifestarse.

La anemia perniciosa (AP) es la principal causa de déficit de cobalamina. Es una enfermedad autoinmune debida a la presencia de anticuerpos dirigidos contra las células parietales y/o contra el factor intrínseco, lo que produce una gastritis crónica atrófica (autoinmune o tipo A) en el cuerpo y fundus del estómago. No suele presentar síntomas y produce aclorhidria (pérdida del pH ácido en el estómago). Se asocia a otras enfermedades autoinmunes (tiroiditis, diabetes mellitus tipo II, vitíligo, etc.).

Otras causas de déficit de vitamina B12 son: dietas vegetarianas estrictas, resección total o parcial del estómago, pancreatitis crónica, enfermedades con afectación de la pared intestinal como la enfermedad de Crohn o la enfermedad celiaca, presencia anómala de microorganismos intestinales, algunos fármacos (metformina, colestiramina, azatioprina) o situaciones donde aumentan las necesidades como es el embarazo.

Las manifestaciones clínicas de la anemia megaloblástica se dividen en:

- Hematológicas: anemia macrocítica megaloblástica con descenso discreto de plaquetas y/o de los glóbulos blancos en estados avanzados.

- Neurológicas: pueden aparecer con o sin anemia e independientemente de su grado. Lo más frecuentes es la aparición de parestesias (sensación de cosquilleo) en los dedos. La complicación más grave es la degeneración de los cordones laterales y posteriores de la médula espinal que produce incapacidad para caminar, lo que se denomina marcha atáxica y espástica. Las alteraciones neuropsiquiátricas son frecuentes en los ancianos en forma de demencia. Todas estas alteraciones pueden mejorar con el tratamiento, pero algunas pueden ser irreversibles.

- Piel y mucosas: palidez cutánea y lengua depapilada con alteración del sentido del gusto.

Para en diagnóstico se precisa:

- Analítica completa: anemia macrocítica con neutrófilos hipersegmentados; aumento de LDH, bilirrubina y homocisteína.

- Cuantificación de vitamina B12: se considera déficit con valores inferiores a $200 \mathrm{pg} / \mathrm{ml}$. Se comprueban los valores ácido fólico y de hierro ya que puede asociarse carencia de ambos.

- Detección de anticuerpos contra factor intrínseco y células parietales: positivos en el $75 \%$ de los casos de AP, aunque su negatividad no excluye el diagnóstico.

- Endoscopia oral: para confirmar histológicamente la gastritis atrófica por medio de la toma de biopsias del antro, cuerpo y fundus gástrico.

El tratamiento consiste en la administración de cobalamina y la corrección de la causa subyacente. Aunque están descritas respuestas al tratamiento por vía oral, la respuesta a altas dosis es impredecible, por lo que se prefiere la vía intramuscular. Se administran 1000 mcg de cianocobalamina al día durante la primera semana, después semanalmente durante el primer mes y posteriormente con periodicidad mensual o bimensual. Los niveles de hierro y ferritina han de ser monitorizados y corregidos. Los pacientes con AP precisarán tratamiento de por vida y en ellos se recomienda realización de endoscopia oral cada 3-4 años.

M. Morado y R de Paz Servicio de Hematología y Hemoterapia. Hospital Universitario La Paz. Madrid 